\title{
Palaeo-productivity record from Norwegian Sea enables North Atlantic Oscillation (NAO) reconstruction for the last 8000
}

\section{years}

\author{
Lukas W. M. Becker $\mathbb{D}^{1,4 凶}$, Hans Petter Sejrup ${ }^{1}$, Berit O. Hjelstuen ${ }^{1}$, Haflidi Haflidason $\mathbb{D}^{1}$, Heidi Kjennbakken ${ }^{2}$ and Johannes P. Werner $^{3}$
}

The North Atlantic Oscillation is the dominant atmospheric driver of North Atlantic climate variability with phases corresponding to droughts and cold spells in Europe. Here, we exploit a suggested anti-correlation of North Atlantic Oscillation-phase and northeastern North Atlantic primary productivity by investigation of south-eastern Norwegian Sea sediment cores spanning the last 8000 years. Age model uncertainties between 2 and 13 years for the period 1992-1850 AD allows for the proxy to observational data calibration. Our data suggest that $\mathrm{Ca} / \mathrm{Fe}$ core-scanning results reflect sedimentary $\mathrm{CaCO}_{3}$ variability in the region. Cross-correlating the $\mathrm{Ca} / \mathrm{Fe}$ record with nearby phytoplankton counts and dissolved $\mathrm{O}_{2}$ data suggests that $\mathrm{Ca} / \mathrm{Fe}$ can be used as a proxy for primary productivity variability in the region. Our data support an anti-correlation of primary productivity to the winter North Atlantic Oscillation index. Hence, we propose a sub-decadally resolved palaeo-North Atlantic Oscillation reconstruction based on an openocean record spanning the last 8000 years.

npj Climate and Atmospheric Science (2020)3:42 ; https://doi.org/10.1038/s41612-020-00147-6

\section{INTRODUCTION}

The North Atlantic Oscillation (NAO) is the dominant driver of atmospheric variability in the North Atlantic region, determining the strength and position of the westerlies, which are the prevailing winds from the west across the North Atlantic. The westerlies strongly influence the surface ocean circulation in the region, affecting current speeds and mixing the surface layers ${ }^{1,2}$. The NAO index is defined as the sea-level pressure difference between the Icelandic Low and the Azores High, a positive (negative) phase generating warmer (colder) and wetter (drier) climate conditions in north-western Europe ${ }^{3}$. The NAO is most pronounced during the winter months (December-March) and varies on timescales ranging from days to centuries ${ }^{4}$. There are currently only a few published pre-instrumental NAO reconstructions based on an open-ocean sediment record ${ }^{5,6}$ among the numerous reconstructions based on palaeo data ${ }^{7-13}$. This is likely due to challenges such as limited temporal resolution and lack of precise (sub-decadal) age control in marine records. However, if these challenges are overcome, marine records could offer insights from, e.g., key features of the North Atlantic circulation and enable the investigation of the important ocean-atmosphere link. Specifically, in regards to a non-stationary phenomenon like the NAO, the ocean-wide "catchment" size can be advantageous. A NAO reconstruction based on an open-ocean proxy record from the North Atlantic has, therefore, the potential to be an important advance on existing proxy-based reconstructions. Several studies have suggested and numerically tested the influence of the NAO on the dynamics of the phytoplankton productivity through air-sea fluxes and its impact on the circulation in the eastern North Atlantic ${ }^{2,14-16}$.

Variability in biogenic calcium carbonate $\left(\mathrm{CaCO}_{3}\right)$ content in marine sediments has been used to infer Quaternary palaeoceanographic changes on glacial-interglacial timescales in the North Atlantic $^{17,18}$. However, the relationship between sediment carbonate and sea-surface conditions is complex, and general statements on such relationships have proven to be difficult to demonstrate. The sources of biogenic $\mathrm{CaCO}_{3}$ in deep-sea sediments are primarily coccolithophores and planktonic foraminifera, followed by pteropods and calcareous dinoflagellates ${ }^{19,20}$. In addition to variability in the productivity of these organisms, the biogenic $\mathrm{CaCO}_{3}$ content in the sediments is diluted through the flux of terrigenous material and may also be affected by chemical dissolution ${ }^{19,21}$. The productivity of $\mathrm{CaCO}_{3}$ secreting algae is essentially constrained by light, nutrients and temperature ${ }^{22}$. As such, productivity has a distinct seasonal cycle, peaking during spring and autumn phytoplankton blooms ${ }^{23}$, but also relays decadal to millennial, climatically driven, changes in the surface water conditions ${ }^{2,24}$.

This study investigates which factors influence $\mathrm{CaCO}_{3}$ concentrations in the slope sediments on the southern Norwegian continental margin. This is done in order to address the following objectives: (i) can ITRAX-derived $\mathrm{Ca} / \mathrm{Fe}$ variability be used as a proxy for changes in sea-surface primary productivity in the region and (ii) how this proxy may reflect known modes of oceanic and atmospheric variability in the region. To address these questions, two well-dated, high-resolution sediment cores covering the last 8000 years were analysed. These cores were collected at 850 and $960 \mathrm{~m}$ water depth on the south-eastern Norwegian margin (Fig. 1a). Both core stratigraphies overlap with the late 20th-century observational time series of sea-surface conditions and productivity, enabling the calibration of proxy to observational data.

\section{RESULTS}

Core location and sediment properties

The eastern Norwegian Sea is directly influenced by the inflow of warm Atlantic surface water through the North Atlantic Current (NAC) (Fig. 1a). Once the NAC crosses the Greenland-Scotland Ridge, the eastern branch is referred to as the Norwegian Atlantic 


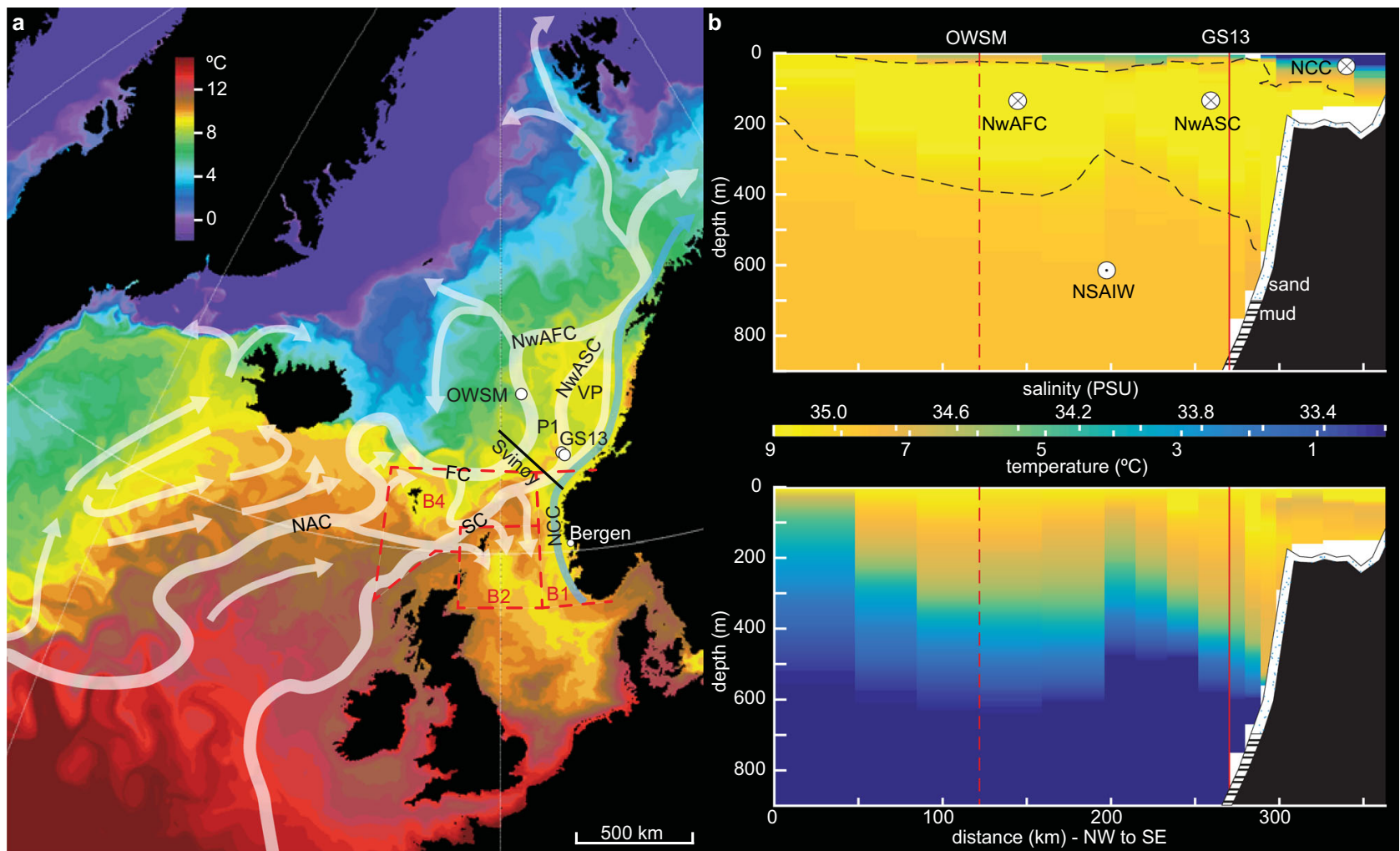

Fig. 1 The position of cores GS13-182-01CC (GS13) and P1-003 MC \& SC (P1). a Ocean Weather Ship Mike (OWSM), the hydrographical Svinøy section and the prevailing surface currents are indicated ${ }^{72}$. Background image courtesy of A.C. Coward (NOC, Southampton, early summer, daily mean sea-surface temperature). Standard areas of the Continuous Plankton Recorder survey ${ }^{40}$ are outlined (stippled red line). Abbreviations are as follows: North Atlantic Current (NAC), Farøe Current (FC), Shetland Current (SC), Norwegian Atlantic Slope Current (NwASC), Norwegian Atlantic Front Current (NwAFC), Norwegian Coastal Current (NCC), Vøring Plateau (VP). b Contour maps of salinity (upper) and temperature (lower) profiles along the Svinøy section during August 1988 (Fig. 1a). The NwAFC and NwASC are outlined at 35 PSU (black stippled line), the NCC and the Norwegian Sea Atlantic Intermediate Water (NSAIW) can be distinguished. The projected position of OWSM (red stippled line), the position of GS13 perpendicular to the Svinøy section (red line) and sediment surface conditions are indicated.

Slope Current (NwASC), and the western branch as the Norwegian Atlantic Front Current (NwAFC). The NwASC is a barotropic shelf edge current, streaming over the Vøring Plateau ${ }^{25}$, while the NwAFC is topographically constrained and flows around the edge of the outer Vøring Plateau (Fig. 1a). The total transport of Atlantic surface water within the NwASC and NwAFC has been estimated to $6.8 \mathrm{~Sv}^{26}$, with salinities $>35.0$ PSU and temperatures of 5-10 ${ }^{\circ} \mathrm{C}^{27}$. The shallow, northwards flowing Norwegian Coastal Current (NCC) covers and partly overlies the surface waters east of the NwASC (Fig. 1b). The surface sediments in water depths up to $700 \mathrm{~m}$ consists of sorted sand and gravel, reflecting high-energy conditions within the Atlantic inflow water. Between 700 and $1200 \mathrm{~m}$ water depth, corresponding to the depth, the presented cores were retrieved from, the surface sediments consist of pelitic mud $^{28}$, reflecting the low-energy regime within the homohaline Norwegian Sea Atlantic Intermediate Waters (NSAIW, Fig. 1b). These pelitic muds, which are considered to be mainly derived from erosion of upper slope and shelf sediments ${ }^{28,29}$ contain $\sim 15-30 \% \mathrm{CaCO}_{3}$ in surface samples ${ }^{28}$, changing to foraminiferal ooze below $1200 \mathrm{~m}$ water depth ${ }^{28}$.

Cores GS13-182-01CC $\left(63.64^{\circ} \mathrm{N}, 05.51^{\circ} \mathrm{E}\right)$, hereafter GS13, and $\mathrm{P} 1-003\left(63.76^{\circ} \mathrm{N}, 05.25^{\circ} \mathrm{E}\right)$ penetrate into the slide debris of the Storegga Slide (Fig. 1a and Supplementary Fig. 1), which is dated to $7650 \pm 250{ }^{14} \mathrm{C}$ years $\mathrm{BP}^{30}$. The slide debris in the lowermost part of GS13 is overlain by $12 \mathrm{~cm}$ of sorted, very fine sands $(77 \%$ $>63 \mu \mathrm{m})$, with a sharp transition into marine mud at $1777.7 \mathrm{~cm}$ (Fig. 2f). The structureless marine mud does not show signs of bioturbation and appears uniform with, on average, $98.5 \%$ silt and clay $(<63 \mu \mathrm{m})$. The remaining $1.5 \%$ of the material $(>63 \mu \mathrm{m})$ consists, on average, to $85 \%$ of very fine sand $(<125 \mu \mathrm{m})$. The age models of both cores are primarily based on Icelandic tephra, radiocarbon and ${ }^{210} \mathrm{~Pb}$ dates and consist of an ensemble of 19,000 equally likely Bayesian age models (see "Methods"). The age model suggests that the accumulation rate in core GS13 is relatively constant from $0.16 \mathrm{~cm}$ per year between ca. 8000 to 2000 a BP, rising to $0.8 \mathrm{~cm}$ per year in the last 1000 years, and on average to $1 \mathrm{~cm}$ per year in the last 100 years (see "Methods" and details on chronological approach in Supplementary Note 1). The increase in accumulation rate appears to be unrelated to sediment-water content as this is relatively constant throughout the core $(\sim 50 \%$ before 1000 a BP, rising to $60 \%$ on average in for the youngest part). Chronological uncertainties are 2-13 years back to $1850 A D$, and $17-190$ for the section from $1850 A D$ to 8000 a BP (see detailed description in "Methods" and on the chronological approach in Supplementary Note 1).

To investigate, if bulk sediment $\mathrm{CaCO}_{3}$ variability is reflected in the bulk elemental composition from an ITRAX X-ray fluorescence (XRF) core scanner, we focused on raw, bulk element XRF Ca counts and $\mathrm{CaCO}_{3}$ measurements at selected depths (see Supplementary Note 2 and Supplementary Fig. 2). The XRF Ca counts were normalised with the counts of a lithogenic element (Fe) to account for closed-sum constrains of compositional data (see "Methods"). The raw $\mathrm{Ca} / \mathrm{Fe}$ time series exhibits distinct changes to relatively high Ca concentration, centered on 5000, 3000, 2000 and 0 a BP (Fig. 2). Comparing the $\mathrm{Ca} / \mathrm{Fe}$ ratio with the $\mathrm{Ca}$ counts normalised with the total kilo counts per second (kcps) does not reveal any major differences, suggesting no 


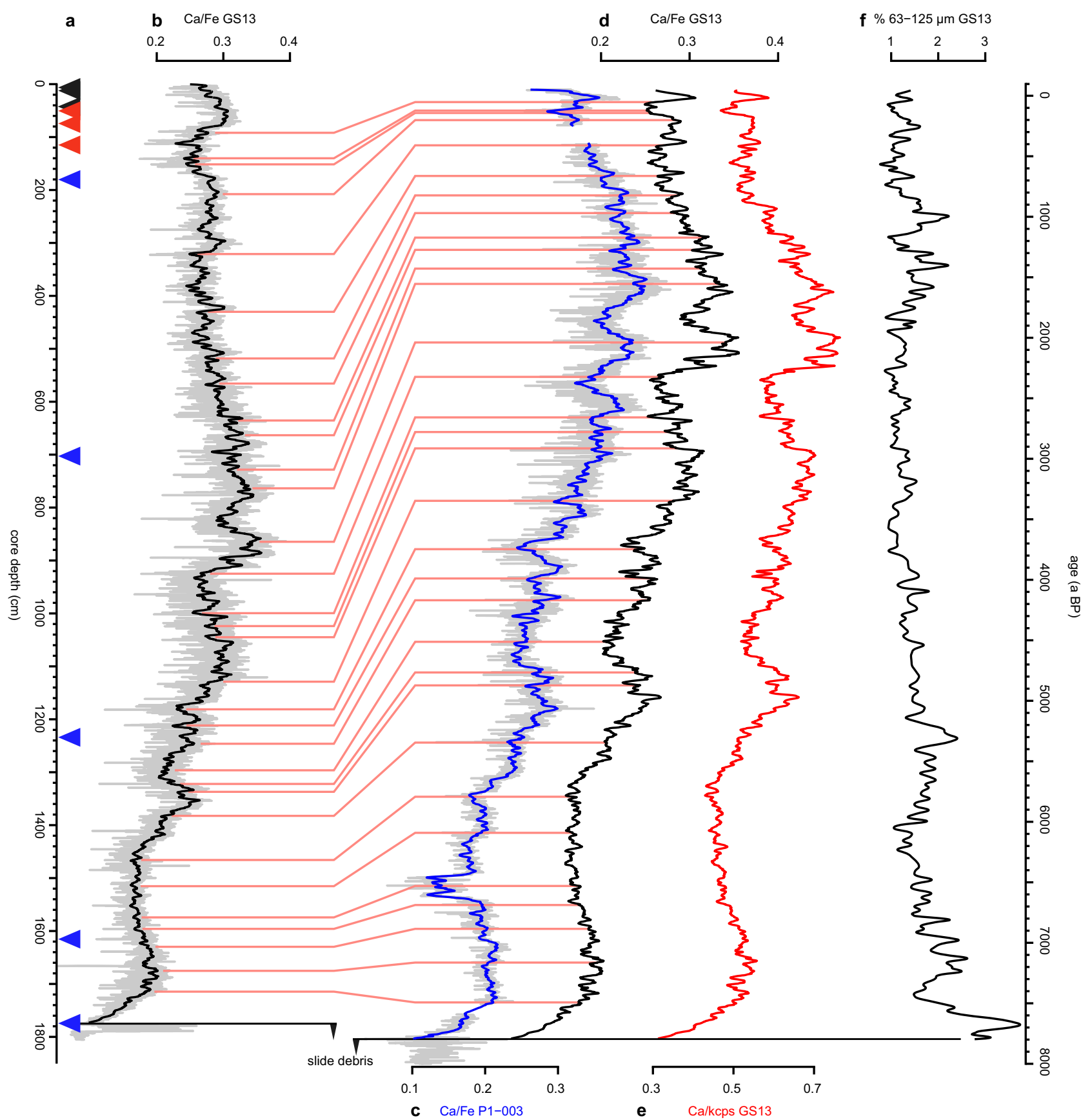

Fig. 2 Correlation of GS13 with P1-003. a The triangles denote dated depths on core GS13 as in ${ }^{210} \mathrm{~Pb} /{ }^{137} \mathrm{Cs}$ events (black), tephra layers (red) and AMS ${ }^{14} \mathrm{C}$ (blue). See Supplementary Table 1 for details. b GS13 Ca/Fe data (black) on depth scale linked with (c) Ca/Fe data of P1-003 (blue) through 33 tie-points, achieved by peak-to-peak correlation (red lines, see Supplementary Note 1 for details). d The resulting Ca/Fe data of GS13 on an age scale (cross-correlation with annually subsampled (c) resulted in $R=0.92$ ). The $\mathrm{Ca} / \mathrm{Fe}$ data have only a marginal difference to $(\mathbf{e})$ the ratio of $\mathrm{Ca} / \mathrm{kcps}$ (total counts in kilo counts per second). The grain-size data (\% 63-125 $\mu \mathrm{m}$ ) of GS13 (f) is relatively constant throughout the core. The variations are not reflected in the $\mathrm{Ca} / \mathrm{Fe}$ data, suggesting no grain-size bias of the XRF counts. All data shown are linearly, annually resampled and filtered using a third-order Savitzky-Golay filter with a 50-year bin-size (200 cm in the case of Fig. 2a); original data in grey.

or little detectable terrigenous influence on the Ca variability (Fig. 2). Furthermore, small variations in the sub-annually resolved very fine sand fraction (Fig. 2f) do not correspond to the variability in the $\mathrm{Ca} / \mathrm{Fe}$ ratio, indicating, that grain-size fluctuations related to current speeds are not principally driving the changes in relative $\mathrm{Ca}$ concentrations. Sortable silt data in the region were earlier interpreted to show lowerfrequency variability related to changes in NwASC current speed ${ }^{31}$. The grain-size data from GS13 are relatively uniform throughout the core, suggesting little direct current speed influence on the terrigenous flux at the core site but this cannot be entirely excluded.

Sources of biogenic $\mathrm{CaCO}_{3}$

The main sources of biogenic $\mathrm{CaCO}_{3}$ in (hemi-)pelagic sediments are commonly foraminifera and coccolithophores with coccoliths often contributing 40-60\%, although usually even more in higher-latitude 
sediments ${ }^{32}$. The $>63 \mu \mathrm{m}$ fraction, where most of the foraminifera are found, generally constitutes $<2 \%$ of the sediment in GS13 $(0.069 \mathrm{~g}$ on average). Foraminiferal assemblage counts throughout the core in the 150-1000 $\mu \mathrm{m}$ fraction, resulted in 64 tests per gram of dry sediment on average, of which $67 \%$ are Neogloboquadrina incompta. With an average weight of ca. $10 \mu \mathrm{g}$ per test of $N$. incompta ${ }^{33}$, it is evident that foraminifera contributes $<0.1 \%$ to every gram dry sediment. This suggests that foraminiferal derived $\mathrm{CaCO}_{3}$ only constitutes an insignificant part of the $\mathrm{CaCO}_{3}$ in the investigated cores, which is in line with previous studies suggesting coccolithophores as the primary source of $\mathrm{CaCO}_{3}$ in the fine fraction of sediments in the Nordic seas ${ }^{34}$. The relative abundance of species Emiliania huxleyi in surface sediments in the Norwegian Sea is ca. $60 \%$, while Coccolithus pelagicus accounts for $\sim 20-40 \%{ }^{35}$. The contribution of $C$. pelagicus to the $\mathrm{CaCO}_{3}$ flux to the sediments is approximately one order of magnitude higher than the contribution of E. huxleyi ${ }^{36}$ due to its larger size. On the North Iceland Shelf, C. pelagicus accounts for $>95 \%$ of the total coccolith carbonate mass throughout the last 8000 years $^{37}$.

We suggest that the $\mathrm{Ca} / \mathrm{Fe}$ time series of the investigated cores primarily reflects $\mathrm{CaCO}_{3}$, which in turn primarily reflects the variability in the deposition of coccoliths, with the species $C$. pelagicus as the main contributor. Factors such as nutrients and irradiance have been suggested as the primary control on the distribution of $C$. pelagicus ${ }^{35,37,38}$. Within the yearly cycle, the highest concentrations of $C$. pelagicus are reported in July in the Norwegian Sea, while the state of preservation increasingly deteriorates throughout the season ${ }^{36}$. Given the evidence and the reasoning for the relation between $\mathrm{Ca} / \mathrm{Fe}$ variability and coccolith abundance described above, we hypothesise that the variability in $\mathrm{Ca} / \mathrm{Fe}$ can be used as a proxy for primary productivity of $\mathrm{CaCO}_{3}$ secreting algae in the south-eastern Norwegian Sea. This relationship might, however, be distorted by the dissolution of the tests before or after they are enclosed in the sediments. Several tests run with scanning electron microscopy revealed no signs of dissolution like overgrowth or increased fragility on the $\mathrm{CaCO}_{3}$ microfossil assemblages investigated in GS13 and P1-003 (Supplementary Figs. 3 and 4). This is in line with previous findings within the Nordic seas ${ }^{39}$. However, postdepositional dissolution will likely have a negligible effect in this case due to the extremely high sedimentation rates, which is underlined by the absence of signs of dissolution in the samples.

\section{$\mathrm{Ca} / \mathrm{Fe}$ measurements and primary productivity variability}

To test if $\mathrm{Ca} / \mathrm{Fe}$ can be used as a proxy for total primary productivity, the $\mathrm{Ca} / \mathrm{Fe}$ data are statistically validated against available instrumental observations of primary productivity. Surface phytoplankton concentrations from the region, as available from the Continuous Plankton Recorder (CPR) survey since 1958 (see "Methods"), are the most direct observation of primary productivity in the region ${ }^{40}$. Available time series of primary productivity observations suggest that $\mathrm{CaCO}_{3}$ secreting plankton (coccolithophores and foraminifera) co-vary with non- $\mathrm{CaCO}_{3}$ secreting plankton (diatoms, dinoflagellates, radiolarians, etc.; Supplementary Fig. 5). Therefore, here, the record of $\mathrm{CaCO}_{3}$ primary producers ${ }^{41}$ is assumed to reflect the total primary production variability in the region (see "Methods"). The time period used for calibration is anomalous from the past due to possible human impact on the marine environment ${ }^{42}$, but the absolute relationship of the boundary conditions to the environment should, however, stay valid.

Cross-correlations suggest a strong link between the $\mathrm{Ca} / \mathrm{Fe}$ record and the summer total phytoplankton concentrations of standard area B4 (Figs 1a and 3a-c). About $84 \%$ of all 19,000 age models (see "Methods") suggest a significant $(P<0.05)$ correlation, while almost $70 \%$ of all age models suggest a lag of 1 or 0 years (Fig. 3b). The median cross-correlation coefficient (R) of all significant fits is $R=0.54$, with the best fits exceeding $R=0.80$ (Fig. 3c and see "Methods"). As expected from the relatively large age uncertainty in the age model input data in the youngest 10 years of the core (see "Methods"), the fit and the spread of age models deteriorate slightly between 1983 and 1993 (Fig. 3a). Notably, the fit of $\mathrm{Ca} / \mathrm{Fe}$ and the autumn and spring data is significantly lower (median $R=0.37$ ), even though the majority of age models still suggest a similarly sized lag, while there is no reasonable correlation with the winter concentrations (Supplementary Fig. 6).

Dissolved $\mathrm{O}_{2}$ data are closely related to the strength of the primary production ${ }^{43}$. Hence, the cross-correlation script was additionally used to evaluate the $\mathrm{Ca} / \mathrm{Fe}$ variability in relation to the seasonally resolved, dissolved $\mathrm{O}_{2}$ data from Ocean Weather Ship Mike (OWSM; integrated over 1-50 m water depth, Fig. 1). Here, only the 10,000 age models with the best fit to standard area B4 were used (Fig. 3a-c). The best cross-correlations were computed with spring/early summer (MAMJJA) dissolved $\mathrm{O}_{2}$ (median $R=$ 0.40). The strong correlation with dissolved $\mathrm{O}_{2}$ in spring/early summer coincides with the main production period, the phytoplankton blooms ${ }^{23}$ and the highest concentrations of $C$. pelagicus in the region ${ }^{36}$.

These results give confidence in using the variability of $\mathrm{Ca} / \mathrm{Fe}$ as a proxy for relative changes in total primary productivity in the south-eastern Norwegian Sea. This conclusion is supported by the trends of $\mathrm{Ca} / \mathrm{Fe}$ closely resembling the temporal variability of phytoplankton mass measured in chlorophyll concentration in the eastern North Atlantic through the last century ${ }^{24}$ (Fig. 4). A very similar trend over the last century is also seen in a recent Greenland ice core-based subarctic Atlantic primary productivity reconstruction ${ }^{44}$. The weak cross-correlation to other available areas with CPR phytoplankton concentration data (including the area linked to the NCC; Fig. 1a and Supplementary Fig. 6) supports the assumption that the $\mathrm{Ca} / \mathrm{Fe}$ record is an open-ocean signal, reflecting the productivity from the inflow trajectory of the Norwegian Atlantic Current into the Norwegian Sea (Supplementary Fig. 6).

\section{DISCUSSION}

A number of studies have suggested that annual primary productivity within the south-eastern Norwegian Sea anticorrelates to the polarity of the $\mathrm{NAO}^{2,15,16,45}$. This effect has been suggested to result from an increase in wind-driven mixing and the enhanced inflow of Atlantic surface waters into the Norwegian Sea through strengthened westerlies during the winter season $^{2,14,46,47}$. These factors disturb the water mass stratification and result in a greater mixed layer depth (MLD) ${ }^{48}$. The shoaling of the MLD in spring is, next to sunlight, an important driver of the onset of the subpolar spring bloom. A greater MLD ultimately delays the start of the spring bloom, effectively shortening the growing season and reducing the magnitude of the phytoplankton bloom and with that the primary production ${ }^{16}$. This effect might be increased through stronger surface currents driving the spatial distribution of the bloom, potentially adding to the net reduction in primary productivity at the core site ${ }^{49}$. Thus, the positive (negative) phase of the NAO leads to decreased (increased) primary production within the south-eastern Norwegian Sea.

To examine a possible correlation between the suggested primary productivity proxy and the $\mathrm{NAO}$, the $\mathrm{Ca} / \mathrm{Fe}$ record of GS13 was cross-correlated to the instrumentally measured, seasonal NAO index of the years $1824-1992$ AD $^{50}$ (Fig. 5 and Table 1). Crosscorrelating the data within the years with the best data quality (1950-1992 AD), the results suggest a significant $(P<0.05)$, robust anti-correlation with the winter NAO (median $R=-0.48$, best fit $R=-0.72$ ) in line with a previously published correlation between proxy-based data and the instrumental NAO record (e.g., Fig. 3 in Ortega et al. ${ }^{10}$ ). The distribution of lags is relatively uniform, with 

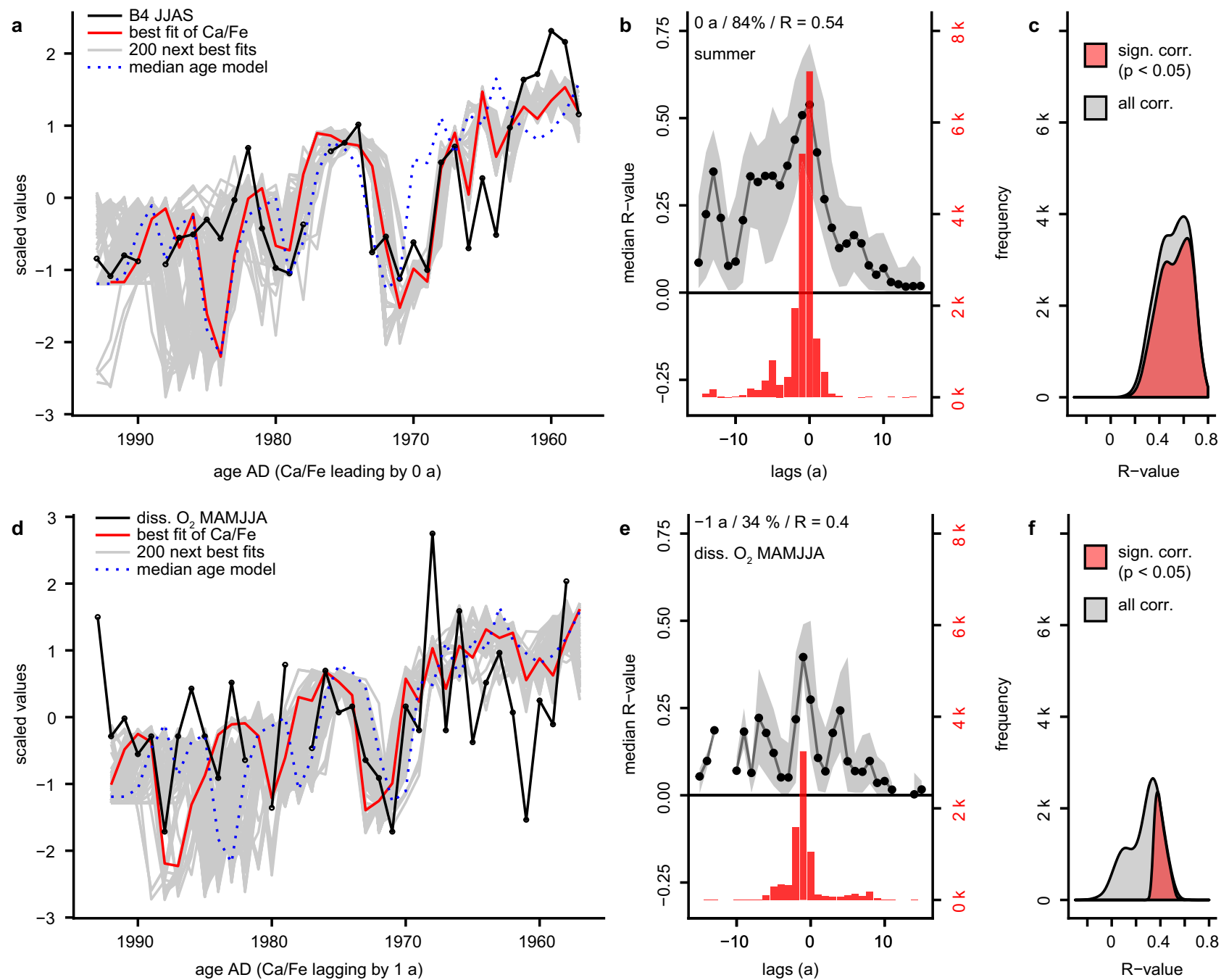

Fig. 3 Proxy calibration with observational data. a Time series (black line with dots) of mean summer (JJAS) total phytoplankton counts (dinoflagellates and diatoms) in standard area B4 of the CPR survey ${ }^{41}$. Best fit (red) while 200 next best fits of Ca/Fe (grey) have a lead/lag of 0 year (mode of the histogram in panel b). Only significant correlations $(P<0.05)$ are used. For orientation, the annually subsampled Ca/Fe on the median age model is also shown (blue, dotted). b Distribution of median cross-correlation coefficients ( $R$-value, black dots) across 31 lead/ lags (negative values denote a lag of $\mathrm{Ca} / \mathrm{Fe}$ relative to compared proxy) underlain by $5-95 \%$ quantiles (grey area). The mode of lag, \% significant age models and the median $R$-value at this lag are given at the top. The histogram denotes at which lead/lag each age model has the highest $R(n=19,000)$. Only significant correlations $(P<0.05)$ are used. $c$ Density plot of the distribution of $\mathrm{R}$ at a lag of 1 year (mode of the histogram in panel b). Significant correlations $(P<0.05$, red) are underlain by all correlations (grey). d-f Same as panel a-c, but with mean spring-early summer (MAMJJA) dissolved $\mathrm{O}_{2}$ data from OWSM integrated over 1-50 m water depth. Only the best-fitting age models of panel b (lag of -1 and $0, n=10,000)$ are used.

most age models suggesting a lag of 0 or 1 year (Fig. 5b). The covariability of the $\mathrm{Ca} / \mathrm{Fe}$ record with the NAO summer, spring and autumn seasons shows a decreasing co-variability throughout the year (Table 1 and Supplementary Fig. 7). Apart from winter and intra-seasonal variability, other seasons therefore most likely influenced the signal as well. However, when extending the cross-correlation to the available instrumental data, i.e., until the year 1824 (Fig. 5d-f), the fit weakens significantly, despite of a similar lag size (median $R=-0.20$, best fit $R=-0.44$, see Table 1 for an overview). This reduction might be caused by several factors, e.g., chronological uncertainties, data quality in the $\mathrm{Ca} / \mathrm{Fe}$ record or data quality degradation in the earlier instrumental NAO data. The change in the degree of correlation might also be a factor of the proposed non-stationarity of the NAO signal. However, the strong correlation between the pressure records from different stations of the southern NAO node ${ }^{51}$ suggests that discrepancy between the instrumental and proxy records are stemming from the proxy data and not from the instrumental data. Taken together, these results and the suggested mechanistic link between primary productivity and NAO variability indicates that $\mathrm{Ca} / \mathrm{Fe}$ in core GS13 does reflect NAO variability in the last ca. 150 years. However, the variance observed in the $\mathrm{Ca} / \mathrm{Fe}$ record can not all be explained by the NAO variability. Apart from influencing factors discussed above such as geochronological uncertainty and sedimentological processes, another climate/weather regimes may explain some of the variability. Tests of the relationship to such regimes pointed to influences of e.g., the Atlantic Multidecadal Oscillation ${ }^{52}$ (AMO; see Supplementary Note 3 and Supplementary Fig. 8) and the subpolar gyre index ${ }^{53}$ (SPG; Supplementary Fig. 9) in the signal. The co-variability between the SPG and the $\mathrm{Ca} / \mathrm{Fe}$ data appears to be strong and direct, but the cross-correlation is limited to a period of 42 years. In conclusion, based on these considerations, we suggest that our 


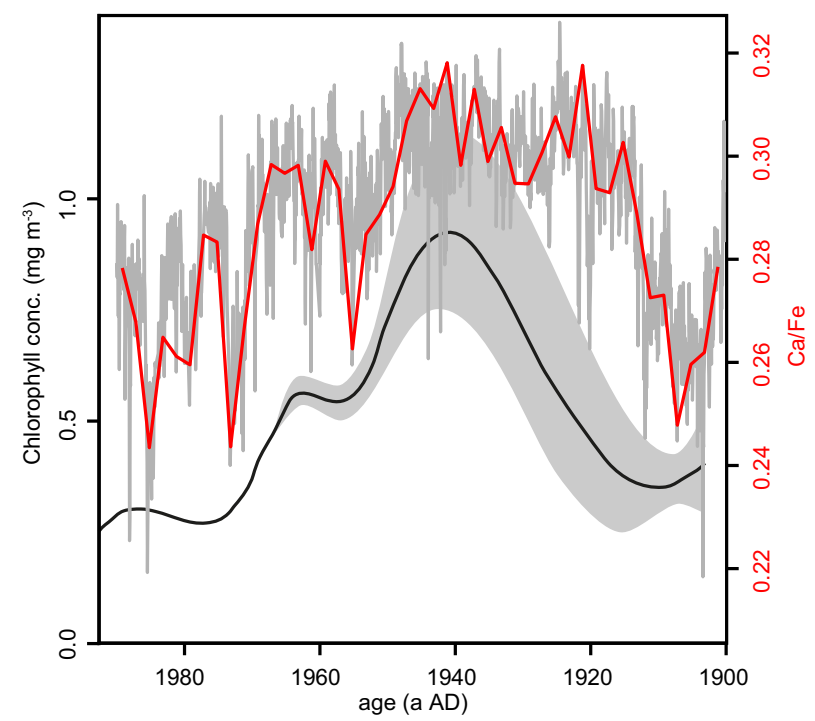

Fig. 4 Annual phytoplankton trends of the North Atlantic as a function of chlorophyll concentration. The previously published, estimated chlorophyll trend of the North Atlantic (black, incl. 95\% credibility area) exhibits a phytoplankton mass decline since the $1940 \mathrm{~s}^{24}$. The Ca/Fe data of core GS13 (grey) mirror this trend closely (in red, biannually, linearly resampled).

$\mathrm{Ca} / \mathrm{Fe}$ record may be used as a proxy for winter NAO variability back in time, beyond instrumental data.

The raw 8000 years, Ca/Fe record of GS13 (Fig. 6b) exhibits a non-stationary signal with a broad frequency range. The underlying lower-frequency component (periods $>500$ a) is removed from the $\mathrm{Ca} / \mathrm{Fe}$ record in the following, as these frequencies may mainly be related to trends in the development of the sedimentary supply system, like the sea level and the geometry of water masses. Additionally, the lower-frequency component shares some similarities with the low-frequency components in the reconstructed total radiocarbon production rate (Fig. 6a), which indicates, among other things, solar activity changes ${ }^{54}$. The higher-frequency components (periods $<500$ a) of the $\mathrm{Ca} / \mathrm{Fe}$ record show annual to (multi-)centennial-scale variability. This part of the record, hereafter $\mathrm{NAO}_{\mathrm{CaFe}}$, is therefore used to reconstruct the NAO variability through the last 8000 years. To improve the readability of the $\mathrm{NAO}_{\mathrm{CaFe}}$ index, the data are bandpass filtered (10-500 a), when focusing on the complete record (Fig. 6e). To investigate only the high-frequency components of the $\mathrm{NAO}_{\mathrm{CaFe}}$ index, the data were additionally high-pass filtered (periods $<100$ a, Fig. 6f) and compared to existing reconstructions (Fig. 7).

The high-frequency components (periods $<100$ a) of $\mathrm{NAO}_{\mathrm{CaFe}}$ correspond relatively well with available NAO reconstructions covering the last 1000 years (Fig. 7). Cross-correlations run with $\mathrm{NAO}_{\text {growth }}{ }^{13}$ (Supplementary Fig. 10) and $\mathrm{NAO}_{\text {med }}{ }^{7}$ (Supplementary Fig. 11) show a significant fit within the last 1000 years (see Table 1 for an overview). Specifically, $N^{\prime} O_{\text {growth }}$ has a good fit within the last 300 years (median $R=0.55$, best fit $R=0.70$ ). $\mathrm{Ca} / \mathrm{Fe}$ correlates in this case directly with a stalagmite growth index, $\mathrm{NAO}_{\text {growth, }}$ as both are proposed to be anti-correlating to the NAO polarity. The fit decreases throughout the last 1000 years (median $R=0.28$, best fit $=0.55$ ) with a still reasonably well peak-to-peak correlation, with the exception of the period between 1200 and 1300 a AD (Supplementary Fig. 10). Before 1000 a AD, the fit decreases further, which could in part be explained by the increasing chronological uncertainties. Notably, $\mathrm{NAO}_{\mathrm{CaFe}}$ does not show a distinct prevailing positive NAO phase during the Medieval Warm Period (MWP), as seen in the $\mathrm{NAO}_{\text {growth, }}$ in line with other studies ${ }^{55}$. The fit to $\mathrm{NAO}_{\text {med }}$ is weaker than the fit to $\mathrm{NAO}_{\text {growth }}$ and best within the last 300 years (median $R=-0.27$, best fit $R=$ -0.45 ). The fit reduces further throughout the last 1000 years (Supplementary Fig. 11, see Table 1 for an overview). The fit to $\mathrm{NAO}_{\mathrm{PC} 1}{ }^{8}$ is of a similar size within the last 300 years, but the crosscorrelation analysis reveals a lag of 39 years. Additionally, $\mathrm{NAO}_{\mathrm{CaFe}}$ corresponds well with a record showing the likelihood (degree of belief) for the NAO being in a specific phase, based on a North Atlantic functional palaeoclimate network ${ }^{56}$. A sign-test between $\mathrm{NAO}_{\mathrm{CaFe}}$ (Fig. 7a) and the degree of belief record (Fig. 7b) of Franke et al. ${ }^{56}$ showed an agreement of $~ 50 \%$ in the last $1000 \mathrm{a}$ (thresholds set to $> \pm 0.001$ in $\mathrm{Ca} / \mathrm{Fe}$ and $>0.5$ in the degree of belief data). For this comparison, a 50 -year running mean is calculated for both records. However, introducing a lag of 25 years into the degree of belief record relative to $\mathrm{NAO}_{\mathrm{CaFe}}$ increases the agreement between the records to $>77 \%$. The lag offset of the degree of belief data could solely be due to uncertainties within the model used to calculate the degree of belief data, with respect to the timing of changes ${ }^{56}$.

Beyond the last 1000 years, reconstructions become scarcer, with only three reconstructions extending beyond 2000 a BP $9,13,57$ (Supplementary Fig. 12). Difficulties in reconstructing a nonstationary signal like the $\mathrm{NAO}^{1}$ become apparent when comparing the available long-term reconstructions with each other, resembling each other only during few periods (Supplementary Fig. 12, and reviewed by Pinto et al. ${ }^{4}$ ). This might again be an effect of a small catchment, which results in an incomplete NAO signal due to a shift in the centre of action of the NAO, as indicated by Lehner et al. ${ }^{55}$. However, the sampling site of GS13 is, as detailed above, influenced by the variations in surface currents of the North Atlantic and the dominant atmospheric modes of the region, giving confidence in recording a regional signal. Thus, it could be argued that the $\mathrm{NAO}_{\mathrm{CaFe}}$ record might be capable of recording a signal, which is less biased by the non-stationarity of the NAO.

In summary, the $\mathrm{NAO}_{\mathrm{CaFe}}$ record shows a relatively robust, statistically significant fit to the instrumentally measured NAO index. Beyond the instrumental time period, $\mathrm{NAO}_{\mathrm{CaFe}}$ has a good fit with $\mathrm{NAO}_{\text {growth }}{ }^{13}$ and a weaker but significant fit to $\mathrm{NAO}_{\text {med }}{ }^{7}$ and $\mathrm{NAO}_{\mathrm{PC} 1}{ }^{8}$ (see Fig. $7 \mathrm{c}-\mathrm{e}$ and Table 1 for an overview of correlation coefficients). Additionally, $\mathrm{NAO}_{\mathrm{CaFe}}$ mostly agrees with the NAO phase indicated by the North Atlantic palaeoclimate network model from Franke et al. ${ }^{56}$ (Figs $6 \mathrm{~d}$ and $7 \mathrm{~b}$ ). Extending beyond 1000 a $\mathrm{BP}, \mathrm{NAO}_{\mathrm{CaFe}}$ agrees with some phases of the available reconstructions (Supplementary Fig. 12). The available reconstructions are however shown to be to some degree inconsistent among each other ${ }^{4,7,8}$, which makes it challenging to assess direct correlations between the reconstructions. Taken together, the primary productivity variability within the southeastern Norwegian Sea reflected in the $\mathrm{Ca} / \mathrm{Fe}$ record shows potential for a NAO index reconstruction throughout the last 8000 years, as it performs at least as well in correlating to the available instrumental NAO data compared to previous reconstructions (Table 1). Comparing the last 8000 years of high-frequency variability of $\mathrm{NAO}_{\mathrm{CaFe}}$ with known climate anomalies like the Little Ice Age (LIA), the MWP and Holocene Thermal Maximum (HTM) (Fig. 6) do not evidence any general changes in the amplitude of the NAO associated with these events. Studying the lowerfrequency variability in the $\mathrm{Ca} / \mathrm{Fe}$ record, there appear to be some trends and phases which may be associated with larger-scale climatic changes. However, it is challenging to determine what part larger-scale changes in ocean current systems are playing and to what extend primary productivity changes reflect this lowfrequency variability. Future studies should focus on a detailed discussion of the Holocene NAO variability and its potential links to known climatic events and human history ${ }^{58,59}$. 

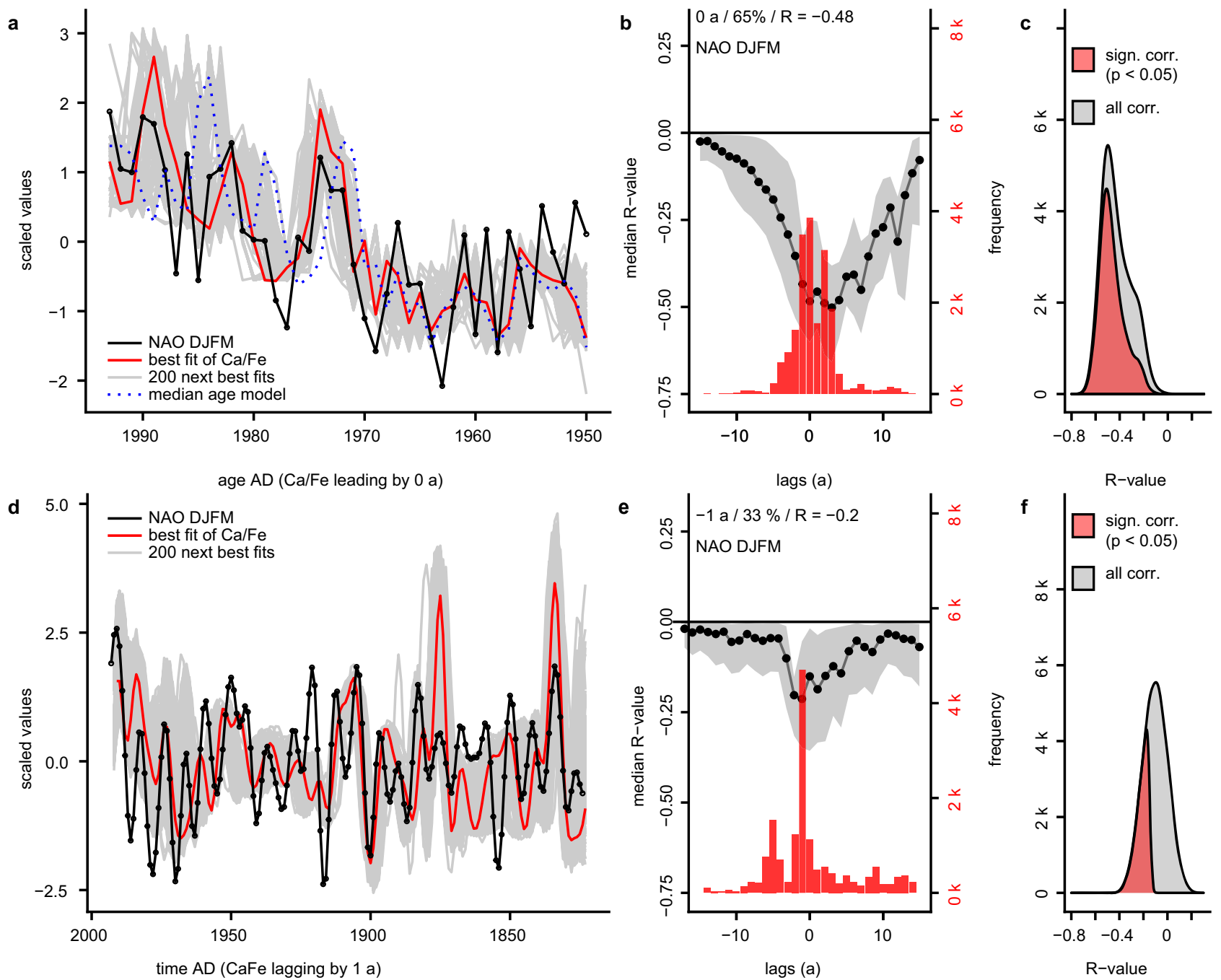

Fig. 5 Cross-correlation analysis with NAO index. a Time series (black line with dots) of mean winter (DJFM), instrumentally observed NAO index ${ }^{50}$. Best fit (red line) and 200 next best fits of $\mathrm{Ca} / \mathrm{Fe}$ (grey line), lagging by 0 years (mode of the histogram in panel b). Only significant correlations $(P<0.05)$ are used. b Distribution of median cross-correlation coefficients $(R$-value, black dots) across 31 lead/lags (negative values denote a lag of $\mathrm{Ca} / \mathrm{Fe}$ relative to compared proxy) underlain by $5-95 \%$ quantiles (grey area). The mode of lag, \% significant age models and the median $R$-value at this lag are given at the top. The histogram denotes at which lead/lag each age model has the highest $R(n=19,000)$. Only significant correlations $(P<0.05)$ are used. $\mathbf{c}$ Density plot of the distribution of $R$ at a lag of 0 year (mode of the histogram in panel $\mathbf{b})$. Significant correlations $(P<0.05$, red area) are underlain by all correlations (grey area). d-f As in panel a-c, but for 1824-1992 (bandpass filtered, periods 3-30 a).

\begin{tabular}{|c|c|c|c|c|c|c|c|}
\hline $\mathrm{NAO}_{\text {winter }}{ }^{50}$ & 1950 & 1992 & -0.48 & -0.73 & 0 & 65 & - \\
\hline $\mathrm{NAO}_{\text {summer }}{ }^{50}$ & 1950 & 1992 & -0.33 & -0.48 & -1 & 13 & - \\
\hline $\mathrm{NAO}_{\text {autumn }}{ }^{50}$ & 1950 & 1992 & -0.1 & -0.25 & -2 & 2 & - \\
\hline $\mathrm{NAO}_{\text {growth }}{ }^{13}$ & 1000 & 1992 & 0.28 & 0.55 & 18 & 97 & $5-100 a$ \\
\hline $\mathrm{NAO}_{\text {med }}{ }^{7}$ & 1700 & 1989 & -0.27 & -0.49 & 17 & 64 & $5-100 a$ \\
\hline $\mathrm{NAO}_{\text {med }}{ }^{7}$ & 921 & 1989 & -0.11 & -0.29 & 0 & 53 & $5-100 \mathrm{a}$ \\
\hline $\mathrm{NAO}_{\mathrm{PC} 1}{ }^{8}$ & 1700 & 1970 & -0.29 & -0.42 & 39 & 47 & $5-100 a$ \\
\hline $\mathrm{NAO}_{\mathrm{PC} 1}{ }^{8}$ & 1241 & 1970 & -0.14 & -0.4 & 41 & 49 & $5-100 a$ \\
\hline
\end{tabular}




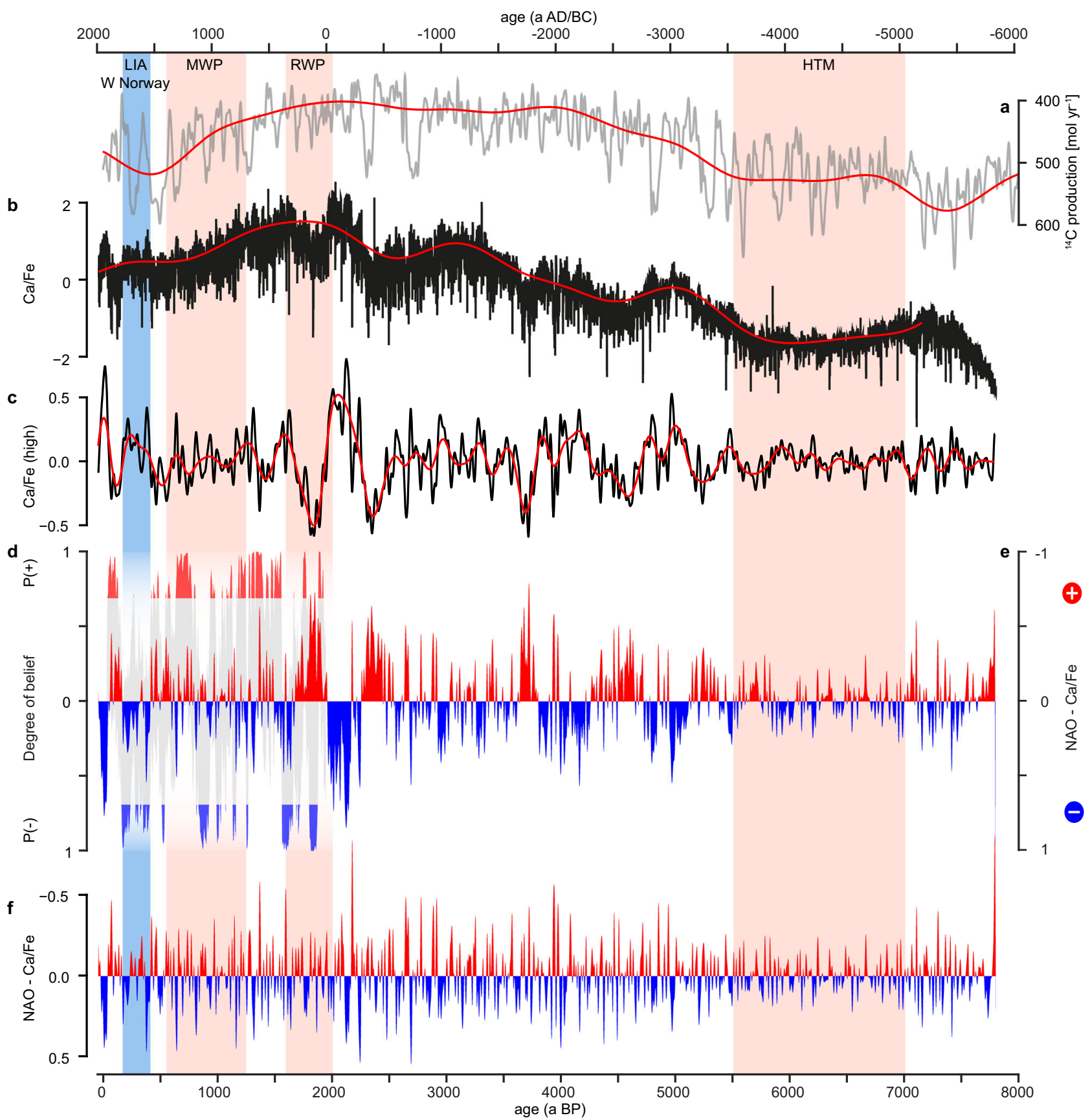

Fig. 6 The complete $\mathrm{NAO}_{\mathrm{CaFe}}$ record. a Total radiocarbon production rate (grey line, inverted) ${ }^{54}$, overlain by low-passed version (red line, inverted, cut-off 500 a). b The raw Ca/Fe data (black line) overlaid with the low-passed version (red line, cut-off 500 a). c Bandpass filtered Ca/ Fe data (10-500 a periods) demonstrating the changing amplitude of the signal through time, lowest amplitudes around the Holocene Thermal Maximum (HTM) and the Medieval Warm Period (MWP). d Degree of belief, that the NAO is in a specific phase (50-year mean; indicated at the start of the window) based on a North Atlantic functional palaeoclimate network ${ }^{56}$. Grey areas indicate where less than $66 \%$ of all ensemble members agreed on the same NAO phase (modified from Franke et al. ${ }^{56}$ ). e The NAO CaFe index consisting of annually resampled, bandpass filtered (cut-off 10-500 a) XRF Ca/Fe data, shown in an inverted, two-coloured plot. f The NAO $\mathrm{CaFe}$ index (annually resampled, bandpass filtered, cut-off 10-100 a, inverted, two-coloured plot). Known, sustained warm periods are marked in light red and respective cold periods in light blue. HTM Holocene Thermal Maximum, RWP Roman Warm Period, MWP Medieval Warm Period, LIA W Norway Little Ice Age western Norway.

\section{METHODS}

\section{Core material}

The 1970-cm long CALYPSO piston core GS13 has raised 18.5-km southsoutheast of core P1-003 at $960 \mathrm{~m}$ water depth (Supplementary Fig. 1), recovering $1777.7 \mathrm{~cm}$ of marine deposits. Core P1-003, collected at $850 \mathrm{~m}$ water depth, is a spliced archive, consisting of a $42-\mathrm{cm}$ long MultiCore (MC) and a $690-\mathrm{cm}$ long SelanticCore $(\mathrm{SC})^{60}$. The top of the SC section was spliced with the MC section at $32.05 \mathrm{~cm}$, in total recovering $670.3 \mathrm{~cm}$ of marine deposits. All core depths presented are on merged and void corrected scales.

\section{Geochemical analysis}

Cores GS13 and P1-003 were analysed for their bulk elemental composition on an ITRAX X-ray fluorescence (XRF) core scanner, using 

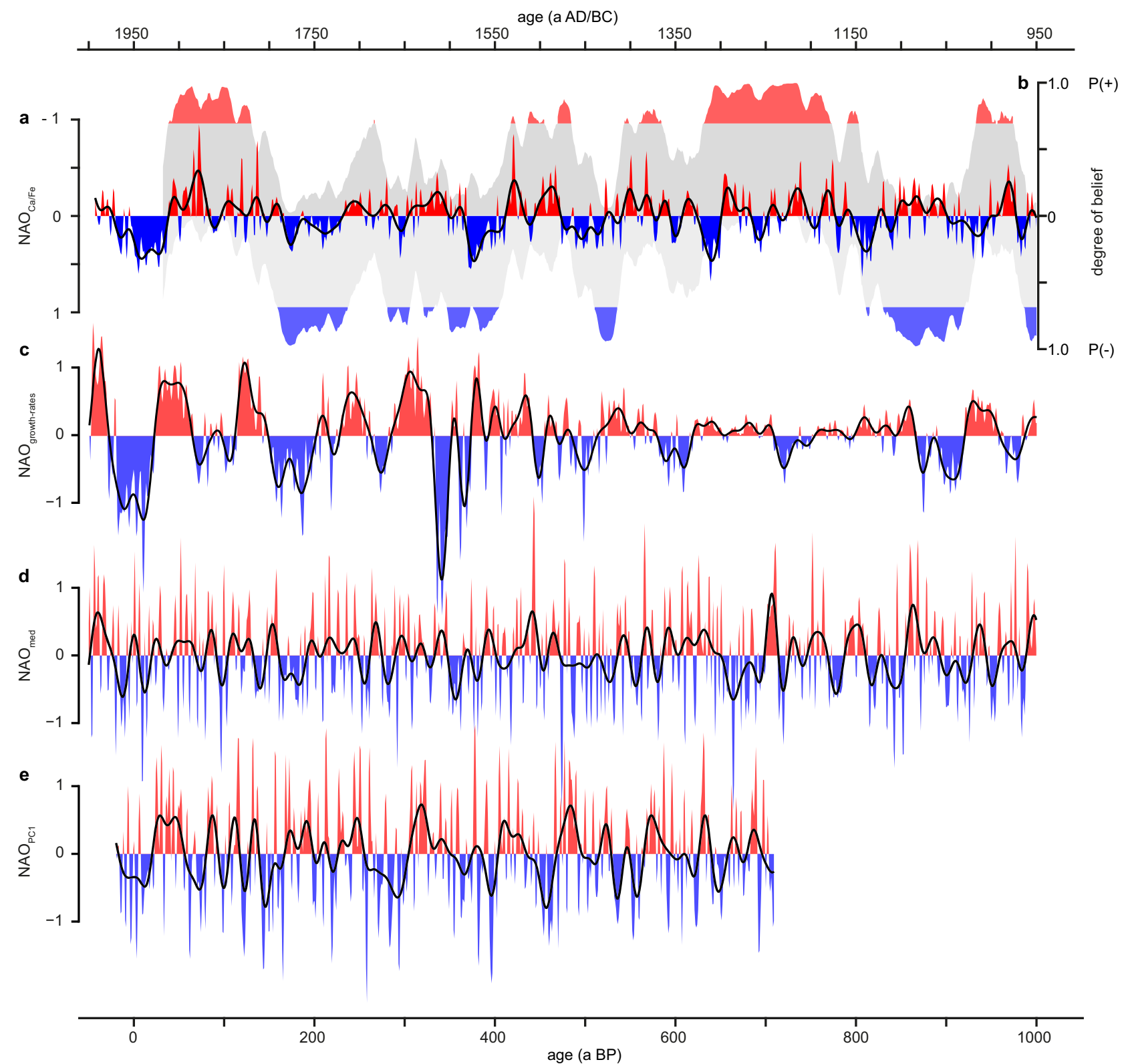

Fig. 7 Comparison of the $\mathrm{NAO}_{\mathrm{CaFe}}$ index with recently published NAO indices for the last 1000 years. a The NAO $\mathrm{CaFe}$ index (two-coloured plot, annually resampled, inverted, bandpass filtered with cut-off period 2-100 a), overlain with the bandpass filtered version (black line, cutoff 10-100 a) as in Fig. 6 f. b Degree of belief, that the NAO is in a specific phase (50-year mean, indicated at the start of the window) based on a North Atlantic functional palaeoclimate network ${ }^{56}$. Grey areas indicate where less than $66 \%$ of all ensemble members agreed on the same NAO phase (modified from ref. ${ }^{56}$ ). c As in (a), but with inverted stalagmite growth rate, $\mathrm{NAO}_{\text {growth }}{ }^{13}$. d As in (a), but with $\mathrm{NAO}_{\text {med }}$ index ${ }^{7}$. e As in panel a, but with $\mathrm{NAO}_{\mathrm{PC} 1}$ index ${ }^{8}$. For a full comparison throughout the last 8000 years, the reader is referred to Supplementary Fig. 12.

the Molybdenum X-ray tube at room temperature. GS13 and P1-003SC were scanned with a resolution of $500 \mu \mathrm{m}$ and a counting time of $10 \mathrm{~s}$ (100 s in P1-003 MC). The present work focuses on the XRF data recorded on GS13, whereas the XRF data from $\mathrm{P} 1-003^{61}$ are primarily used for age model refinement (Figs. 2 and 8). The XRF core-scanning technique produces semi-quantitative elemental counts rather than elemental concentrations. Grain-size variations can influence the elemental counts ${ }^{62}$, but the homogenous grain-size distribution (about $2 \%>63 \mu \mathrm{m}$, Fig. 2) indicates little grain-size bias of the XRF scanning results. To account for closed-sum constraints ${ }^{62}$, the $\mathrm{Ca}$ counts were normalised with the respective Fe counts (Fig. 2). Normalisation with other lithogenic elements like $\mathrm{Ti}$ or K yielded very similar results (Supplementary Fig. 13). The log transformation of XRF ratios has been suggested to overcome closed-sum constraints $^{63}$. However, once applied to GS13, the time series were practically identical, indicating a normal distribution of the XRF data. For simplification, the log transformation has thus not been applied. Additionally, interstitial water content and water films forming below the plastic foil can also impact XRF scan results ${ }^{64}$. For this study, the cores were immediately scanned after splitting the cores, hence reducing potential water-film issues. The sediment-water content increases throughout the core linearly from 50 to $60 \%$, suggesting only little influence on the XRF scan results. The comparison of the down-core $\mathrm{Ca}$ intensities with the $\mathrm{Cl}$ intensities confirmed this assessment (Supplementary Fig. 13).

\section{Chronology}

To establish chronological control of GS13, the planktonic foraminiferal species Neogloboquadrina incompta and Globigerina bulloides were picked in the $125-150 \mu \mathrm{m}$ fraction for accelerator mass spectrometry (AMS) radiocarbon dating at INSTAAR, the University of Colorado at Boulder. The 

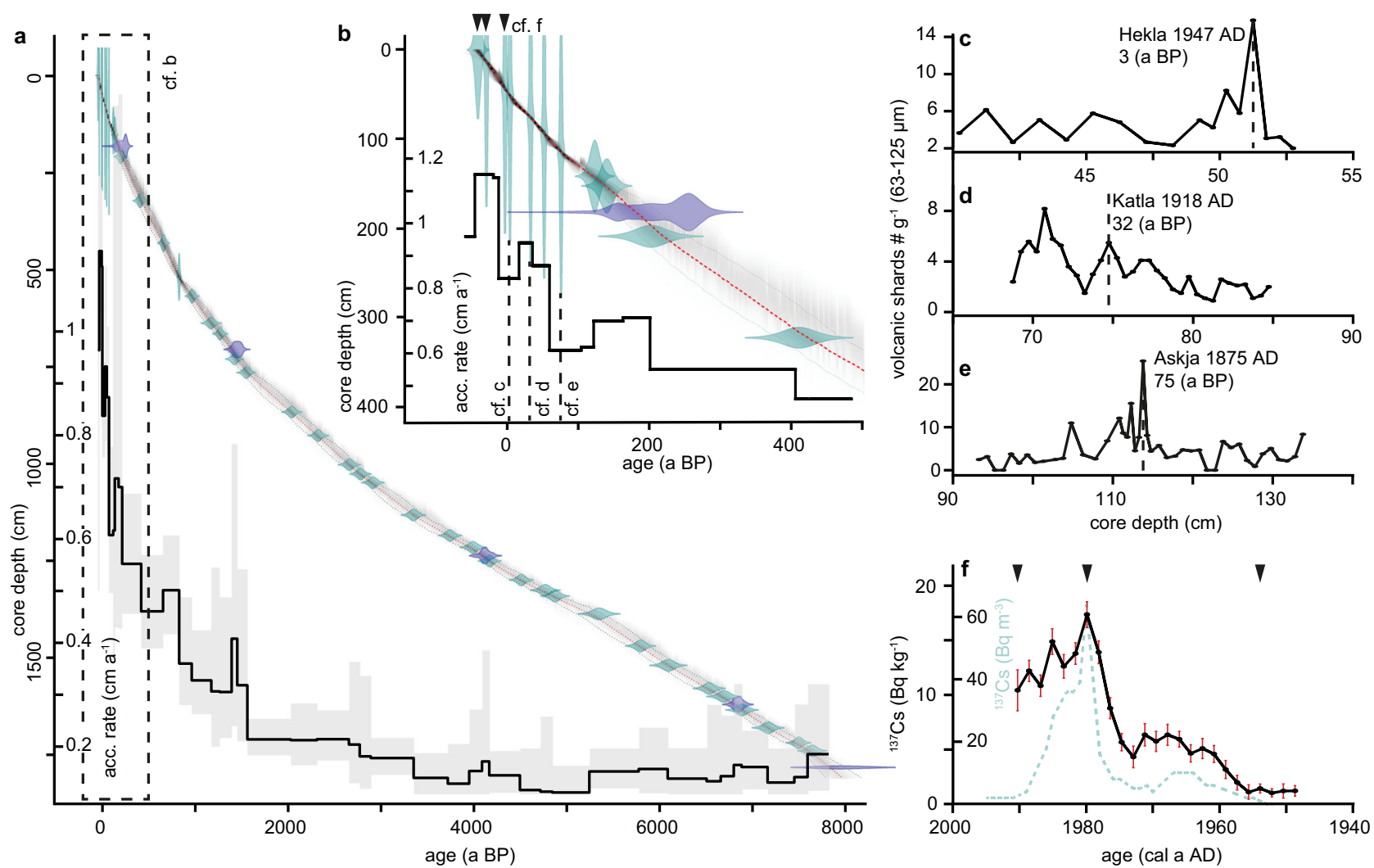

Fig. 8 The age model of GS13. a AMS ${ }^{14} \mathrm{C}$ dates (blue), ${ }^{210} \mathrm{~Pb} /{ }^{137} \mathrm{Cs}$, tephra and Ca/Fe tie-points (green). The grey shaded area denotes the $95 \%$ confidence interval and the red line represents the median age model. The blue stippled line denotes the median age model of the original age model without tie-points, the black stippled lines mark its $95 \%$ confidence interval. The accumulation rate of the median age model (black line) is calculated between each dated depth and underlain by 5-95\% quantiles (grey area). b Enlarged view of the last 550 years. For interpretation of the black triangles, indicating ${ }^{137} \mathrm{Cs}$ events, see panel f. c-e Tephra counts of basaltic-intermediate and rhyolitic shards in the $63-125 \mu \mathrm{m}$ fraction, denoting the number of shards connected to three separate eruptions, for details see Supplementary Note $1 . \mathbf{f}$ All ${ }^{137} \mathrm{Cs}$ measurements from ${ }^{210} \mathrm{~Pb} /{ }^{137} \mathrm{Cs}$ dating $(n=25)$ compared to the total ${ }^{137} \mathrm{Cs}$ concentration in the SW Barents Sea ${ }^{73}$. The triangles denote the ${ }^{137} \mathrm{Cs}$ events used for age modelling. See Supplementary Table 1 for age model input.

radiocarbon dates were converted to calendar years, using the local delta $\mathrm{R}^{60,65}$ and calibration curve Marine $13^{66}$ (Supplementary Table 1). Furthermore, based on the counting of basaltic-intermediate and rhyolitic type of volcanic shards in the $63-125 \mu \mathrm{m}$ fraction, three Icelandic tephra were identified (Hekla 1947, Katla 1918 and Askja 1875, Fig. 8c-e). Finally, continuous $2-\mathrm{cm}$ wide samples were taken in the top $50 \mathrm{~cm}$ of core GS13 for ${ }^{210} \mathrm{~Pb} /{ }^{137} \mathrm{Cs}$ dating, analysed at Eawag, ETH Zürich. With this chronological information, an initial age model was established for GS13 using the Bayesian age modelling package "rbacon" (v. 2.3.6) ${ }^{67}$ within R. To further decrease the chronological uncertainty beyond $1850 \mathrm{AD}$, the age model was refined with a detailed correlation of the XRF Ca/Fe signal (Fig. 2) to the welldated, nearby core P1-003 ${ }^{60,65}$ (Supplementary Fig. 14 and Supplementary Table 2). All chronological information was combined in a final age model run, calculating the final age model (Fig. 8a). The two-sigma uncertainty of the age model is $\sim 2-13$ (average 5) years within the last 150 years, which increases to $\sim 2-24$ (average 7) years within the last 200 years. Before the year $1800 \mathrm{AD}$ and until $0 \mathrm{AD} / \mathrm{BC}$, the two-sigma uncertainty of the age model is 17-110 (average 52) years and $~ 58-190$ (average 100) years for the remainder of the core. For more details on the chronology see Supplementary Note 1.

\section{Analysis of subsamples}

Subsamples in $0.5 \mathrm{~cm}$ slices $\left(\sim 13 \mathrm{~cm}^{3}\right)$ were taken at $5 \mathrm{~cm}$ interval throughout core GS13, except for the top $2 \mathrm{~m}$ of the core, which were sampled continuously. The subsamples were each treated with $35 \%$ hydrogen peroxide $\left(\mathrm{H}_{2} \mathrm{O}_{2}\right)$, shaken for $48 \mathrm{~h}$ at $150 \mathrm{rpm}$ and subsequently wet sieved with a sieve mesh size of 63,125, 150 and $1000 \mu \mathrm{m}$ (Fig. 2). Subsamples (43 samples in $0.5-1-\mathrm{cm}$ slices) from core $\mathrm{P} 1-003$ were used to measure absolute element concentrations of $\mathrm{CaCO}_{3}$, calcium oxide $(\mathrm{CaO})$ and iron oxide $\left(\mathrm{Fe}_{2} \mathrm{O}_{3}\right)$ with the sequential spectrometer Philips $1404 \mathrm{X}$-ray, using wavelength dispersive X-ray Fluorescence ${ }^{61}$. Furthermore, the total inorganic carbon content (TIC) of selected subsamples from P1-003 ${ }^{61}$ was measured with the multi EA 4000 for Macro Elemental Analysis (Analytik Jena). The percentage of $\mathrm{CaCO}_{3}$ was calculated from the TIC content assuming that all evolved $\mathrm{CO}_{2}$ was derived from the dissolution of $\mathrm{CaCO}_{3}$, using the molecular weight ratio of $\mathrm{CaCO}_{3}$ to carbon (8.33), where $~ 85 \%$ of the samples are averages of replicate measurements (Supplementary Fig. 2). Internal standards were included in every run in a ratio of 3:10, indicating a measurement uncertainty of ca. $3 \%$.

\section{Statistical analysis}

The time series were exclusively downsampled during re-sampling, using linear interpolation, with ca. 20 points per year in the youngest sections and ca. 4 points per year in the oldest sections of GS13. Similarly, $R$ was used to compute the annual mean values of the ensemble of age models produced during the age modelling process. This was done to enable the computation of cross-correlations in respect to chronological uncertainties. The cross-correlation script takes advantage of the Bayesian age model output, which produced $\sim 19,000$ equally probable age models, covering the total spread of age uncertainty for each depth in the core (for details see description of the chronological approach in Supplementary Note 1). The script computes about 19,000 cross-correlations, allowing for leads/ lags of up to 15 years, resulting in about 600,000 possible combinations. The leads/lags were increased to 50 if longer ( $>100$ years) time series were cross-correlated. The resulting matrix was then further analysed, statistically verified and corrected for autocorrelation with the "cor.test" function. This function uses Pearson's product-moment correlation coefficient and tests the significance $(P<0.05)$. The result is corrected for the reduced number of degrees of freedom of autocorrelated time series using the autocorrelation parameter (AR1) of both time series, following Bartlett ${ }^{68}$. 
All annual re-sampling and filtering of the acquired data were performed with the "stats" package (v. 4.0.1) in $\mathrm{R}^{69}$. All plotting was performed with packages "ggplot2" and "cowplot" in $\mathrm{R}^{69}$.

\section{Observational productivity data}

The median chronology calculated 1993 AD as the core top age, hence there is an overlap of $\sim 40$ years between available instrumentally measured time series and proxy data. The CPR survey has been recording and counting various plankton species in surface waters at up to daily intervals, across the North Atlantic since 1958, integrating the results in standard areas ${ }^{40}$. The most proximal standard area with sufficient valid data is B4, upstream of GS13 (Fig. 1a). For this study, the sum of total dinoflagellate and total diatom counts were used as an approximation of primary productivity changes ${ }^{41}$. These "total phytoplankton" data are therefore primarily based on $\mathrm{SiO}_{2}$-producing algae. Valid coccolithophore counts are only available between 1999 and 2016. During the time of overlap, these parameters appear to covariate $(r=0.81$, summer in standard area B4, Supplementary Fig. 5), suggesting that the variability in the "total phytoplankton" concentrations in this area can also be used as a proxy for the productivity variability of $\mathrm{CaCO}_{3}$-secreting algae. At OWSM (Fig. 1a) monthly measurements of temperature and dissolved oxygen were carried out from 1948 to 2008 at depths between 0 and $2000 \mathrm{~m}^{46,48}$. The data from OWSM for this study were quality checked and integrated over 1-50 m water depth, avoiding potentially erroneous surface measurements ${ }^{46}$, while covering the depth of highest coccolithophore production $^{70}$. Additionally, as the surface waters on the core site might occasionally be mixed with water from the NCC (Fig. 1b) ${ }^{71}$, integrating the data down to $50 \mathrm{~m}$ water depth would ensure an Atlantic, open-ocean signal. Seasonal means of each year in CPR and OWSM data were calculated from monthly mean data, from winter to autumn, averaging over months DJFM, MAMJ, JJAS and SOND, respectively. The seasonal mean was discarded if data of $>1$ month were not available.

\section{DATA AVAILABILITY}

The data analysed during this study are available from the PANGAEA data repository.

Received: 16 November 2019; Accepted: 11 October 2020; Published online: 13 November 2020

\section{REFERENCES}

1. Hurrell, J. W., Kushnir, Y., Ottersen, G. \& Visbeck, M. In The North Atlantic Oscillation: Climatic Significance and Environmental Impact Geophysical Monograph Series (eds Hurrell, J. W., Kushnir, Y., Ottersen, G. \& Visbeck, M.) 1-35 (American Geophysical Union, 2003).

2. Skogen, M. D., Budgell, W. P. \& Rey, F. Interannual variability in Nordic seas primary production. ICES J. Mar. Sci. 64, 889-898 (2007).

3. Wanner, H. et al. North Atlantic oscillation-concepts and studies. Surv. Geophys 22, 321-382 (2001)

4. Pinto, J. G. \& Raible, C. C. Past and recent changes in the North Atlantic oscillation. Wiley Interdiscip. Rev. Clim. Change 3, 79-90 (2012).

5. Curran, M. J., Rosenthal, Y., Wright, J. D. \& Morley, A. Atmospheric response to mid-Holocene warming in the northeastern Atlantic: Implications for future storminess in the Ireland/UK region. Quat. Sci. Rev. 225, https://doi.org/10.1016/j. quascirev.2019.106004 (2019).

6. Morley, A., Rosenthal, Y. \& deMenocal, P. Ocean-atmosphere climate shift during the mid-to-late Holocene transition. Earth Planet. Sci. Lett. 388, 18-26 (2014).

7. Cook, E. R. et al. A Euro-Mediterranean tree-ring reconstruction of the winter NAO index since 910 C.E. Clim. Dyn. 53, 1567-1580 (2019).

8. Sjolte, J. et al. Solar and volcanic forcing of North Atlantic climate inferred from a process-based reconstruction. Clim 14, 1179-1194 (2018)

9. Faust, J. C., Fabian, K., Milzer, G., Giraudeau, J. \& Knies, J. Norwegian fjord sediments reveal NAO related winter temperature and precipitation changes of the past 2800 years. Earth Planet. Sci. Lett. 435, 84-93 (2016).

10. Ortega, P. et al. A model-tested North Atlantic Oscillation reconstruction for the past millennium. Nature 523, 71-74 (2015).

11. Trouet, V., Scourse, J. D. \& Raible, C. C. North Atlantic storminess and Atlantic Meridional Overturning Circulation during the last Millennium: reconciling contradictory proxy records of NAO variability. Glob. Planet. Change 84-85, 48-55 (2012).
12. Goslin, J. et al. Holocene centennial to millennial shifts in North-Atlantic storminess and ocean dynamics. Sci. Rep. 8, 12778 (2018).

13. Baker, A., C. H., J., Kelly, B. F., Mariethoz, G. \& Trouet, V. A composite annualresolution stalagmite record of North Atlantic climate over the last three millennia. Sci. Rep. 5, 10307 (2015).

14. Drinkwater, K. F. et al. In The North Atlantic Oscillation: Climatic Significance and Environmental Impact Geophysical Monograph Series (eds Hurrell, J. W., Kushnir, Y., Ottersen, G. \& Visbeck, M.) 211-234 (American Geophysical Union, 2003).

15. Glen Harrison, W. et al. Phytoplankton production and growth regulation in the Subarctic North Atlantic: a comparative study of the Labrador Sea-Labrador/ Newfoundland shelves and Barents/Norwegian/Greenland seas and shelves. Prog. Oceanogr. 114, 26-45 (2013).

16. Henson, S. A., Dunne, J. P. \& Sarmiento, J. L. Decadal variability in North Atlantic phytoplankton blooms. J. Geophys. Res. 114, https://doi.org/10.1029/2008jc005139 (2009).

17. Peck, V. L. et al. The relationship of Heinrich events and their European precursors over the past $60 \mathrm{ka}$ BP: a multi-proxy ice-rafted debris provenance study in the North East Atlantic. Quat. Sci. Rev. 26, 862-875 (2007).

18. Rothwell, R. G. \& Croudace, I. W. in Micro-XRF Studies of Sediment Cores Developments in Paleoenvironmental Research (eds Croudace, lan W. \& Guy Rothwell, R.) Chapter 1, 1-21 (Springer Science, 2015).

19. Henrich, R. Dynamics of Atlantic water advection to the Norwegian-Greenland Sea-a time-slice record of carbonate distribution in the last 300 ky. Mar. Geol. 145, 95-131 (1998).

20. Schneider, R. R., Schulz, H. D. \& Hensen, C. in Marine Geochemistry (eds Schulz, Horst D. \& Zabel, M.) Chapter 9, 283-308 (Springer, 2006).

21. Helmke, J. P., Bauch, H. A. \& Erlenkeuser, H. Development of glacial and interglacial conditions in the Nordic seas between 1.5 and 0.35Ma. Quat. Sci. Rev. 22, 1717-1728 (2003).

22. Sakshaug, E. \& Slagstad, D. A. G. Light and productivity of phytoplankton in polar marine ecosystems: a physiological view. Polar. Res. 10, 69-86 (1991).

23. Chiswell, S. M., Calil, P. H. R. \& Boyd, P. W. Spring blooms and annual cycles of phytoplankton: a unified perspective. J. Plankton Res. 37, 500-508 (2015).

24. Boyce, D. G., Lewis, M. R. \& Worm, B. Global phytoplankton decline over the past century. Nature 466, 591-596 (2010).

25. Orvik, K. A. \& Niiler, P. Major pathways of Atlantic water in the northern North Atlantic and Nordic Seas toward Arctic. Geophys. Res. Lett. 29, 2-1-2-4 (2002).

26. Høydalsvik, F. et al. Transport estimates of the Western Branch of the Norwegian Atlantic Current from glider surveys. Deep Sea Res. Part I Oceanogr. Res. Pap. 79, 86-95 (2013).

27. Orvik, K. A., Skagseth, O. \& Mork, M. Atlantic infow to the Nordic Seas: current structure and volume fluxes from moored current meters, VM-ADCP and SeaSoarCTD observations, 1995-1999. Deep Sea Res. Part I Oceanogr. Res. Pap. 48 937-957 (2001).

28. Sejrup, H. P. et al. Benthonic foraminifera in surface samples from the Norwegian Continental margin between $62^{\circ} \mathrm{N}$ and $65^{\circ} \mathrm{N}$. J. Foraminifer. Res. 11, 277-295 (1981).

29. Holtedahl, H. \& Bjerkli, K. Late Quaternary sediments and stratigraphy on the continental shelf off Møre-Trøndelag, W. Norway. Mar. Geol. 45, 179-226 (1982).

30. Haflidason, $\mathrm{H}$. et al. The storegga slide: architecture, geometry and slide development. Mar. Geol. 213, 201-234 (2004).

31. Tegzes, A. D., Jansen, E., Lorentzen, T. \& Telford, R. J. Northward oceanic heat transport in the main branch of the Norwegian Atlantic Current over the late. Holocene. Holocene 27, 1034-1044 (2017).

32. Broecker, W. \& Clark, E. Ratio of coccolith $\mathrm{CaCO}_{3}$ to foraminifera $\mathrm{CaCO}_{3}$ in late Holocene deep sea sediments. Paleoceanogr 24, PA3205 (2009).

33. Barker, S. \& Elderfield, H. Foraminiferal calcification response to glacial-interglacial changes in atmospheric CO2. Science 297, 833-836 (2002).

34. Daniels, C. J. et al. Species-specific calcite production reveals Coccolithus pelagicus as the key calcifier in the Arctic Ocean. Mar. Ecol. Prog. Ser. 555, 29-47 (2016).

35. Baumann, K. H., Andruleit, H. \& Samtleben, C. Coccolithophores in the Nordic Seas: comparison of living communities with surface sediment assemblages. Deep Sea Res. Part II Top. Stud. Oceanogr. 47, 1743-1772 (2000).

36. Samtleben, C. \& Bickert, T. Coccoliths in sediment traps from the Norwegian Sea. Mar. Micropaleontol. 16, 39-64 (1990).

37. Giraudeau, J., Jennings, A. E. \& Andrews, J. T. Timing and mechanisms of surface and intermediate water circulation changes in the Nordic Seas over the last 10,000 cal years: a view from the North Iceland shelf. Quat. Sci. Rev. 23, 2127-2139 (2004).

38. Dylmer, C. V., Giraudeau, J., Hanquiez, V. \& Husum, K. The coccolithophores Emiliania huxleyi and Coccolithus pelagicus: Extant populations from the Norwegian-Iceland Seas and Fram Strait. Deep Sea Res. Part I Oceanogr. Res. Pap. 98, 1-9 (2015)

39. Andruleit, H. Coccolithophore fluxes in the Norwegian-Greenland Sea: Seasonality and assemblage alterations. Mar. Micropaleontol. 31, 45-64 (1997). 
40. Batten, S. D. et al. CPR sampling: the technical background, materials and methods, consistency and comparability. Prog. Oceanogr. 58, 193-215 (2003).

41. Continous Plankton Recorder Survey (SAHFOS). Dataset https://doi.org/10.7487/ 2019.37.1.1166. http://192.171.193.159/doi-library/lukas-becker.aspx (2019)

42. Perner, K. et al. An oceanic perspective on Greenland's recent freshwater discharge since 1850. Sci. Rep. 9, 17680 (2019).

43. Mountford, K. Measuring dissolved oxygen as an indicator of primary productivity. Chesap. Sci. 10, 327-330 (1969).

44. Osman, M. B. et al. Industrial-era decline in subarctic Atlantic productivity. Nature 569, 551-555 (2019).

45. Mork, K. A. \& Blindheim, J. Variations in the Atlantic inflow to the Nordic Seas, 1955-1996. Deep Sea Res. Part I Oceanogr. Res. Pap. 47, 1035-1057 (2000).

46. Nilsen, J. E. Ø. \& Falck, E. Variations of mixed layer properties in the Norwegian Sea for the period 1948-1999. Prog. Oceanogr. 70, 58-90 (2006).

47. Lien, V. S., Budgell, P., Ådlandsvik, B. \& Svendsen, E. Validating results from the model ROMS, with respect to volume transports and heat fluxes in the Nordic Seas. Technical Report Fisken og Havet 2/2006. (Institute of Marine Research, Bergen, Norway, 2006).

48. Blindheim, J. et al. Upper layer cooling and freshening in the Norwegian Sea in relation to atmospheric forcing. Deep Sea Res. Part I Oceanogr. Res. Pap. 47, 655-680 (2000).

49. Oziel, L. et al. Faster Atlantic currents drive poleward expansion of temperate phytoplankton in the Arctic Ocean. Nat. Commun. 11, 1705 (2020).

50. Jones, P. D., Jonsson, T. \& Wheeler, D. Extension to the North Atlantic oscillation using early instrumental pressure observations from Gibraltar and south-west Iceland. Int J. Climatol. 17, 1433-1450 (1997).

51. Vinther, B. M., Andersen, K. K., Hansen, A. W., Schmith, T. \& Jones, P. D. Improving the Gibraltar/Reykjavik NAO index. Geophys. Res. Lett. 30, 2222 (2003).

52. Gray, S. T., Graumlich, L. J., Betancourt, J. L. \& Pederson, G. T. A tree-ring based reconstruction of the Atlantic Multidecadal Oscillation since 1567 A.D. Geophys. Res. Lett. 31, L12205 (2004).

53. Hátún, H., Sandø, A. B., Drange, H., Hansen, B. \& Valdimarsson, H. Influence of the Atlantic subpolar gyre on the thermohaline circulation. Science 309, 1841-1844 (2005).

54. Roth, R. \& Joos, F. A reconstruction of radiocarbon production and total solar irradiance from the Holocene ${ }^{14} \mathrm{C}$ and $\mathrm{CO}_{2}$; records: implications of data and model uncertainties. Clim 9, 1879-1909 (2013).

55. Lehner, F., Raible, C. C. \& Stocker, T. F. Testing the robustness of a precipitation proxy-based North Atlantic Oscillation reconstruction. Quat. Sci. Rev. 45, 85-94 (2012).

56. Franke, J. G., Werner, J. P. \& Donner, R. V. Reconstructing late Holocene North Atlantic atmospheric circulation changes using functional paleoclimate networks. Clim 13, 1593-1608 (2017).

57. Olsen, J., Anderson, N. J. \& Knudsen, M. F. Variability of the North Atlantic Oscillation over the past 5,200 years. Nat. Geosci. 5, 808-812 (2012).

58. Buntgen, U. et al. 2500 years of European climate variability and human susceptibility. Science 331, 578-582 (2011).

59. Drake, B. L. Changes in North Atlantic oscillation drove population migrations and the collapse of the Western Roman Empire. Sci. Rep. 7, 1227 (2017).

60. Sejrup, H. P. et al. Response of Norwegian Sea temperature to solar forcing since 1000 A.D. J. Geophys. Res. 115, C12034 (2010).

61. Kjennbakken, H. Holocene High-resolution Paleoclimate Records from Voldafjorden and the SE Norwegian Sea. PhD thesis, University of Bergen, 135 (2013).

62. Löwemark, L. et al. Normalizing XRF-scanner data: a cautionary note on the interpretation of high-resolution records from organic-rich lakes. J. Asian Earth Sci. 40, 1250-1256 (2011).

63. Weltje, G. J. \& Tjallingii, R. Calibration of XRF core scanners for quantitative geochemical logging of sediment cores: theory and application. Earth Planet. Sci. Lett. 274, 423-438 (2008).

64. Hennekam, R. \& de Lange, G. X-ray fluorescence core scanning of wet marine sediments: methods to improve quality and reproducibility of high-resolution paleoenvironmental records. Limnol. Oceanogr. -Meth. 10, 991-1003 (2012).

65. Sejrup, H. P., Haflidason, H. \& Andrews, J. T. A Holocene North Atlantic SST record and regional climate variability. Quat. Sci. Rev. 30, 3181-3195 (2011).

66. Reimer, P. J. et al. IntCal13 and marine13 radiocarbon age calibration curves 0-50,000 years cal BP. Radiocarbon 55, 1869-1887 (2013).

67. Blaauw, M. \& Christen, J. A. Flexible paleoclimate age-depth models using an autoregressive gamma process. Bayesian Analysis 6, 457-474, https://doi.org/ 10.1214/11-ba618 (2011).
68. Bartlett, M. S. Some aspects of the time-correlation problem in regard to tests of significance. J. R. Stat. Soc. 98, 536-543 (1935).

69. R Core Team. R: A language and environment for statistical computing v. 4.0.1. (R Foundation for Statistical Computing, Vienna, Austria, 2020). https://www.Rproject.org/.

70. Haq, B. U. In Introduction to Marine Micropaleontology (eds Haq, B. U. \& Boersma, A.) 79-107 (Elsevier Science B.V., 1998).

71. Sætre, R. \& Ljøen, R. The Norwegian coastal current. Port and Ocean Engineering Under Arctic Conditions. 514-535 (1971).

72. Hansen, B. \& Østerhus, S. North Atlantic-Nordic Seas exchanges. Prog. Oceanogr. 45, 109-208 (2000).

73. Gao, Y., Drange, H., Bentsen, M. \& Johannessen, O. M. Tracer-derived transit time of the waters in the eastern Nordic Seas. Tellus B 57, 332-340 (2005).

\section{ACKNOWLEDGEMENTS}

The research leading to these results received funding from the GLANAM (GLAciated North Atlantic Margins) Initial Training Network, a People Program (Marie Curie Actions) of the European Union Seventh Framework Program FP7/2007-2013 under REA grant agreement no 317217. All sediment analyses were done at the national infrastructure EARTHLAB (NRC 226171) at the University of Bergen. The authors acknowledge V. Hope, A.J.-G. Becker, J. Wiest, T. Schwestermann and R.H. Rúnarsdóttir for their extensive laboratory work. The authors thank the two anonymous reviewers for their constructive comments, which improved the paper. Finally, the authors would like to thank B. Reinardy for proofreading.

\section{AUTHOR CONTRIBUTIONS}

L.B., H.P.S. and B.H. designed the study and wrote the paper. L.B., H.H. and H.K. carried out sedimentological and geochemical core work. L.B. designed and calculated the chronology. J.W. and L.B. designed and carried out the statistical data analysis. H.H. and L.B. counted and analysed tephra shards. All authors helped edit the paper.

\section{COMPETING INTERESTS}

The authors declare no competing interests.

\section{ADDITIONAL INFORMATION}

Supplementary information is available for this paper at https://doi.org/10.1038/ s41612-020-00147-6.

Correspondence and requests for materials should be addressed to L.W.M.B.

Reprints and permission information is available at http://www.nature.com/ reprints

Publisher's note Springer Nature remains neutral with regard to jurisdictional claims in published maps and institutional affiliations.

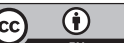

Open Access This article is licensed under a Creative Commons Attribution 4.0 International License, which permits use, sharing, adaptation, distribution and reproduction in any medium or format, as long as you give appropriate credit to the original author(s) and the source, provide a link to the Creative Commons license, and indicate if changes were made. The images or other third party material in this article are included in the article's Creative Commons license, unless indicated otherwise in a credit line to the material. If material is not included in the article's Creative Commons license and your intended use is not permitted by statutory regulation or exceeds the permitted use, you will need to obtain permission directly from the copyright holder. To view a copy of this license, visit http://creativecommons. org/licenses/by/4.0/.

(c) The Author(s) 2020 